\title{
A Complex Legal Framework for a Lack of Legal Certainty: Case Study of Romania
}

\author{
Sergiu Bogdan
}

\section{Contents}

1 National Legal Framework Related to Illicit Tobacco Trade/Smuggling ............... 214

1.1 Substantive Law Issues: Criminal Offenses ............................... 214

1.1.1 Law No. 86/2006 on the Customs Code of Romania ................. 214

1.1.2 Law No. 227/2015 Regarding the Romanian Tax Code ............... 219

1.1.3 Law No. 241/2005 on Tax Evasion ............................. 219

1.2 Substantive Law Issues: Administrative Law ............................ 220

1.2.1 Government Decision No. 707/2006 for the Approval of the Regulation in Regard to the Application of the Customs Code of Romania .......... 220

1.2.2 Law No. 227/2015 on Tax Code ............................... 223

1.2.3 Law No. 12/1990 on the Protection of the Population Against Illicit Production, Trade and Services ................................. 223

1.2.4 Fiscal Responsibility for Illicit Trade ........................... 224

1.3 Relation Between Criminal and Administrative/Fiscal Responsibility ........... 226

1.4 Relations Between Criminalisation of Illicit Trade of Tobacco and Other Types

of Economic Crimes ........................................... 227

1.4.1 The Relationship Between the Smuggling Offense (Article 270 (3) of Law No. 86/2006 on the Customs Code of Romania) and the Offense Provided by Article 452 Letter d) of Law No. 227/2015 (Tax Code) ................ 227

1.4.2 The Relationship Between the Smuggling Offense (Article 270 of Law No. 86/2006) and the Offense of Tax Evasion (Article 9 Para. 1 of Law No. $241 / 2005) \ldots \ldots \ldots \ldots \ldots \ldots \ldots \ldots \ldots \ldots \ldots \ldots \ldots \ldots \ldots \ldots \ldots \ldots \ldots \ldots \ldots \ldots$
The Relationship Between the Smuggling Offense (Article 270 of Law

1.4.3 The Relationship Between the Smuggling Offense (Article 270 of Law
No. 86/2006) and the Money Laundering Offense (Article 49 Para. 1 c) of Law No. 129/2019) ...........................................

1.4.4 The Relationship Between the Smuggling Offense (Article 270 of Law No. 86/2006) and Organized Crime Offense (Article 367 of the Criminal Code) .................................. 229

1.4.5 The Relationship Between Illicit Trade of Tobacco and Corruption ....... 229

The research for the present chapter included both legal framework and case-law analysis (cc. 400 court sentences).

Note: Translated into English by George Zlati and Andra Maria Coț.

\footnotetext{
S. Bogdan (凶)

Faculty of Law, University Babeș-Bolyai, Cluj-Napoca, Romania

e-mail: sbogdan@law.ubbcluj.ro
} 
1.4.6 The Relationship Between Illicit Trade of Tobacco and Organised Crime .. 230

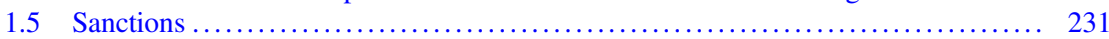

1.5.1 Aggravating Circumstances ................................. 231

1.5.2 Sanctions Applicable for Illicit Trade of Tobacco Products with Regard

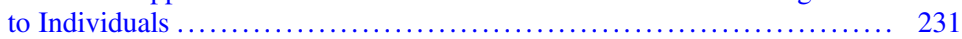

1.6 Legal Responsibility of Legal Entities ............................... 233

1.7 Disposal or Destruction of Confiscated Tobacco Products .................. 235

1.8 Asset Recovery Related to Illicit Trade of Tobacco Products .................. 236

1.9 The Impact of the WTO FCTC and the 2012 Protocol to the FCTC

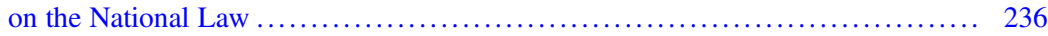

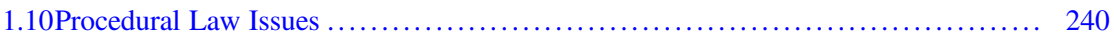

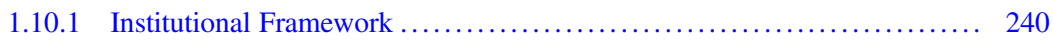

1.10 .2 Procedural Rules ............................................ 241

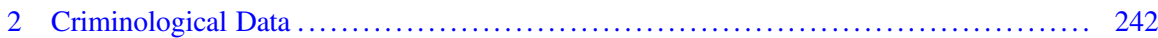

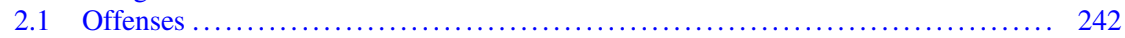

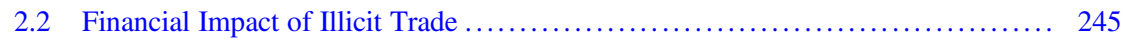

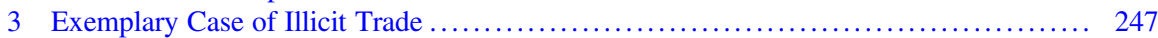

4 Methods and Other Phenomenological Details Related to Illicit Trade of Tobacco

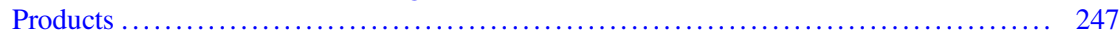

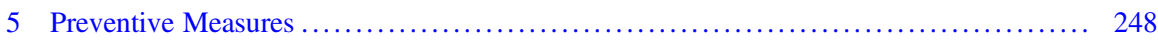

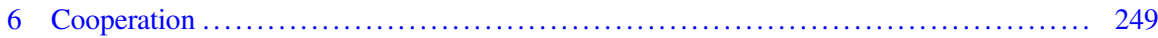

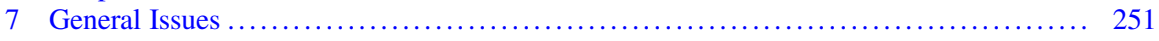

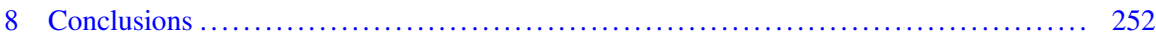

\begin{abstract}
The chapter deals with Romanian legal framework related to illicit trade in tobacco products, both in criminal and administrative law. Criminological data as well as preventive measures on illicit trade in tobacco products in Romania are also presented. In addition, various aspects of cooperation matters concerning control and prevention of the illicit trade of tobacco products in Romania, which due to its geographical location deals with significant flows of illegal cigarettes from non-EU Member States.
\end{abstract}

\title{
1 National Legal Framework Related to Illicit Tobacco Trade/Smuggling
}

\subsection{Substantive Law Issues: Criminal Offenses}

\subsubsection{Law No. 86/2006 on the Customs Code of Romania}

The notion of "smuggling" does not have a legal definition in the Romanian legal system. However, the illicit trade or smuggling of tobacco is an offense according to a variety of criminal provisions that will be discussed below. 
Article 270 of Law no. 86/2006 [Customs Code] ${ }^{1}$ is the most relevant and the most frequently used criminal provision in regard to illicit trade and smuggling of tobacco products.

The offense stipulates in para. (1) that the introduction into or removal from the country, by any means, of goods or merchandise through places other than those established for customs control constitutes a smuggling offense and is punishable by imprisonment from 2 to 7 years and the prohibition of certain rights. In this case the criminal deed (introduction into or removal from the country of goods and merchandise) must take place in any other place than those established for customs control. The scope of article 270 is not narrowed to illicit trade of tobacco products, as it applies to goods of merchandise subject to excise duties. Smuggling tobacco products through the places established for customs control also constitute an offense, only under para. (2) of art. 270. This criminal provision stipulates that it also constitutes an offense the following: (a) introduction into or removal from the country through the places established for customs control by removal from customs control of the goods or goods to be placed under a customs procedure if the customs value of the goods or stolen goods is greater than 20,000 lei [cc. 4,200 euro - note] for products subject to excise duties and more than 40,000 lei [cc. 8,400 euro - note] for other goods or commodities; $(b)$ the introduction into or removal from the country, twice in any one year, through the places laid down for customs control, by removal from customs control of the goods or goods to be placed under a customs procedure if the customs value of the goods or stolen goods is less than 20,000 lei for products subject to excise duty and less than 40,000 lei for other goods or commodities; (c) the alienation of goods in customs transit in any form.

Nonetheless according to article 270 para. (3) the act of collecting, possessing, producing, transporting, taking over, storing, handing over, disposing of and selling

\footnotetext{
${ }^{1}$ Article 270 of Law no. 86/2006: “(1) The introduction into or removal from the country, by any means, of goods or merchandise through places other than those established for customs control constitutes the smuggling offense and shall be punished by imprisonment from 2 to 7 years and the prohibition of certain rights.

(2) It also constitutes a smuggling offense and is punished according to par. (1):

(a) the introduction into or removal from the country through the places established for customs control by removal from customs control of the goods or goods to be placed under a customs procedure if the customs value of the goods or stolen goods is greater than 20,000 lei [cc. 4,200 euro - note] for products subject to excise duties and more than 40,000 lei [cc. 8,400 euro - note] for other goods or commodities;

(b) the introduction into or removal from the country, twice in any one year, through the places laid down for customs control, by removal from customs control of the goods or goods to be placed under a customs procedure if the customs value of the goods or stolen goods is less than 20,000 lei for products subject to excise duty and less than 40,000 lei for other goods or commodities;

(c) the alienation of goods in customs transit in any form.

(3) They are assimilated to the smuggling offense and shall be punished according to par. (1) collecting, possessing, producing, transporting, taking over, storing, handing over, disposing of and selling the goods or merchandise to be placed under a customs procedure knowing that they are smuggled or intended to be smuggled."
} 
the goods or merchandise to be placed under a customs procedure knowing that they are smuggled or intended to be smuggled are assimilated to the smuggling offense.

This offense can be committed both by individuals or legal entities, and it has the purpose to protect the social good consisting in the "customs regime". By smuggling tobacco products, the state suffers a damage consisting of the value of taxes and excise duties that are not paid by the perpetrator to the public budget.

The notion of "smuggling" was up the debate in a preliminary judgement (decision no. 32/2015 ${ }^{2}$ ) of the High Court of Cassation and Justice [Înalta Curte de Casație și Justiție]. At the origin of the preliminary judgement was a reference made by Alba Iulia Court of Appeal. The question raised by the Alba Iulia Court of Appeal in regard to article 270 para. (3) of the Law no. 86/2006 was the following: If the notion of "smuggling" used by the legislator in the provisions of art. 270 par. (3) of the Law no. 86/2006 in the phrase "knowing that they come from smuggling" refers to the offense of smuggling in the sense defined by art. 270 par. (1) and (2) of Law no. 86/2006 or the notion of "smuggling" in a broad sense; if it is established that the text provided by art. 270 par. (3) of the Law no. 86/2006 on the Customs Code of Romania refers to the offense of smuggling, which of the two ways is to be considered: that provided by art. 270 par. (1) or that provided by art. 270 par. (2) of the Law no. 86/2006 on the Customs Code of Romania.

In answering this question the High Court of Cassation and Justice emphasized that the notion of "smuggling" used by the legislator in the provisions of art. 270 par. (3) of the Law no. 86/2006 on the Customs Code of Romania in the phrase "knowing that they come from smuggling" concerns the smuggling of the goods or merchandise to be placed under a customs regime in places other than those established for customs control or introduction in the country of these goods or merchandise through the places established for customs control by evading customs control.

Below a relevant case law in regard to article 270 of Law no. 86/2006 is being cited. In one of the cases, during the period February-March 2019, the defendant had smuggled cigarettes, and on March 21, 2019, he owned and transported the quantity of 2111 packets of smuggled cigarettes, in a car having a specially arranged compartment. ${ }^{3}$ The defendant received a sentence of imprisonment of 1 year and 4 months, the execution of which was suspended under supervision. The assessed damage was to the amount of 23.111 lei. The cigarettes were all seized.

In another case, on 15.01.2019, a search was carried out at the defendant's home, on which occasion, in the kitchen of the building, were identified 5120 unmarked cigarette cartridges, for which he could not present documents of origin. ${ }^{4}$ The defendant received a sentence of imprisonment of 2 years, the execution of which

\footnotetext{
${ }^{2}$ Available at the following link: https://www.scj.ro/1093/Detalii-jurisprudenta?customQuery\% 5B0\%5D.Key=id\&customQuery\%5B0\%5D.Value $=126163$. Accessed on 19 April 2020.

${ }^{3}$ Cluj Court of Appeal, criminal section, decision no. 1413/2019. www.rolii.ro/hotarari/ 5de71f01e49009581600004e. Last accessed on 20 April 2020.

${ }^{4}$ Timișoara Court of Appeal, criminal section, decision no. 1215/2019. www.rolii.ro/hotarari/ 5de71f42e49009780400003f. Last accessed on 20 April 2020.
} 
was suspended under supervision. The assessed damage was to the amount of 65.538 lei. The cigarettes were all seized.

A different defendant was found, holding at the point of work of the individual enterprise a number of 1005 of cigarette packages, different brands, without stamp or with a stamp issued in the Republic of Moldova. ${ }^{5}$ The defendant received a sentence of imprisonment of 1 year and 3 months, the execution of which was suspended under supervision. The assessed damage was to the amount of 11.224 lei.

In the market, a defendant was found on 16.12.2016 and 20.06.2017, having in his possession 480 packs of cigarettes (in his car), respectively 19 packages of cigarettes, all having stamps from Republic of Moldova. ${ }^{6}$ The defendant received a sentence of imprisonment of 1 year and 10 months, the execution of which was suspended under supervision.

Another defendant transported, along with another person, the quantity of 2990 packs of Winston cigarettes and 88 packs of Viceroy cigarettes, having stamps issued by Republic of Moldova. ${ }^{7}$ The defendant received a sentence of imprisonment of 3 years, the execution of which was suspended under supervision.

The offense stipulated under article 272 of Law no. 86/2006 [Customs Code] ${ }^{8}$ is also important in regard to illicit trade and smuggling of tobacco products. This criminal provision has the legal nature of a preparatory criminal deed (an inchoate offense) in relation with the offense of smuggling provided by article 270 of Law no. 86/2006. It covers the deed of using deceptive documents [e.g. documents issued for other goods or merchandise] in front of customs authority. From a conceptual point of view this offense is similar to traditional fraud [article 244 of the Criminal Code] by using deceptive documents with the purpose to obtain an illicit gain.

This offense can be concurrent with the offense provided under article 270 of Law no. 86/2006. ${ }^{9}$ It was held by the Court that during 2014, the defendant, in order to complete the customs formalities for importing a container with 3560000 unmarked cigarettes, used customs and transport documents (electronic document of import, certificate of origin of goods, external invoice, Packing List related to Invoice, letter of authority regarding the correction information sent by the consignor to the Romanian customs authority etc.), documents referring to goods and quantities other than those actually presented in customs.

\footnotetext{
${ }^{5}$ Galați Court of Appeal, criminal section, decision no. 1344/2019. www.rolii.ro/hotarari/ 5de087a0e490093809000044. Last accessed on 20 April 2020.

${ }^{6}$ Iași Court of Appeal, criminal section, decision no. 801/2019. www.rolii.ro/hotarari/ 5dd74cf1e49009881a000042. Last accessed on 20 April 2020.

${ }^{7}$ Galați Court of Appeal, criminal section, decision no. 1027/2019. www.rolii.ro/hotarari/ 5dae5cd9e49009582100002d. Last accessed on 20 April 2020.

${ }^{8}$ Article 272 of Law no. 86/2006: "Using in front of customs authority of transport or commercial documents relating to other goods or merchandise or to other quantities of goods or merchandise than those presented to customs constitutes the offense of using deceptive documents and is punished by imprisonment from 2 to 7 years and the prohibition of certain rights".

${ }^{9}$ See Timișoara Court of Appeal, criminal section, decision no. 1089/2015. www.rolii.ro/hotarari/ 58951a26e490096c25000b4b. Last accessed on 20 April 2020.
} 
Article 273 of Law no. $86 / 2006^{10}$ is similar to article 272 but covers the deed of using falsified documents in front of customs authority. ${ }^{11}$ This offense does not cover the forgery of the documents used in front of customs authority. As a consequence, the forgery of the documents in question can also raise a criminal liability under articles 320-322 of the Criminal Code [offenses regarding counterfeiting of documents]. In a Court decision

Article 274 of Law no. 86/2006 ${ }^{12}$ covers an aggravating circumstance-when the deed provided under article $270-273$ is being committed by one or more armed individuals or by two or more individuals together. In a Court decision it was stated that "this [aggravated] circumstance applies when two persons jointly own or transport together or produce together or trade together, etc. these quantities of cigarettes. This [aggravated] circumstance does not apply, however, when one person delivers and another takes the same quantity of cigarettes, or one person transports and another deposits the same quantity, or one person markets and another holds after purchasing the same quantity". ${ }^{13}$

An armed individual does not need to use the weapon if it consists in a tool, device or part of a device declared as such by the law [see article 179 para. 1 of the Criminal Code ${ }^{14}$ ]. If an object is used for attack in order to commit an offense then such an object will be considered a weapon according to the law [see article 179 para. 2 of the Criminal Code ${ }^{15}$ ].

A brief analysis of the case law concerning the offense under article 270 of Law no. $86 / 2006$ shows that the offense is mostly committed by two or more persons together. ${ }^{16}$

\footnotetext{
${ }^{10}$ Article 273 of Law no. 86/2006: "Using in front of customs authority of forged customs documents related to transport or merchandise constitutes the offense of using falsified documents and is punished by imprisonment of 3 to 10 years and the prohibition of certain rights".

${ }^{11}$ See Iaşi Court of Appeal, criminal section, decision no. 513/2016. www.sintact.ro/\#/jurispru dence/529929532/1/decizie-penala-nr-513-2016-din-30-iun-2016-curtea-de-apel-iasi-infractiunila-regimul-vamal-legea...?keyword $=$ Decizia\%20513 2F2016\&cm $=$ SREST. Last accessed on 20 April 2020.

${ }^{12}$ Article 274 of Law no. 86/2006: "The deeds provided under article 270-273, committed by one or more armed persons or by two or more persons together, shall be punished by imprisonment from 5 to 15 years and the prohibition of certain rights."

${ }^{13}$ Iași Court of Appeal, criminal section, decision no. 482/2018. www.rolii.ro/hotarari/ 5b853746e49009881f00002f. Last accessed on 20 April 2020.

${ }^{14}$ Article 179 para. 1 of the Criminal Code: "Weapons mean tools, devices or parts declared as such by legal stipulations".

${ }^{15}$ Article 179 para. 2 of the Criminal Code: "Any other objects likely to be used as weapons and which have been used for attacks shall be assimilated to weapons".

${ }^{16}$ See High Court of Cassation and Justice, criminal section, decision no. 614/2013. www.scj.ro; Suceava Court of Appeal, criminal section, decision no. 338/2016. www.rolii.ro/hotarari/ 5899f8ffe49009e83e001622. Last accessed on 20 April 2020; Oradea Court of Appeal, criminal section, decision no. 141/2017. www.rolii.ro/hotarari/58d6790de49009f41b00003a. Last accessed on 20 April 2020; Suceava Court of Appeal, criminal section, decision no. 152/2017. www.rolii.ro/ hotarari/58bfc4c8e49009d41a000073. Last accessed on 20 April 2020; Suceava Court of Appeal, criminal section, decision no. 2336/2012; Suceava Court of Appeal, criminal section, decision
} 
Article 275 of Law no. 86/2006 stipulates that the attempt to commit the offenses provided under articles 270-274 is also punishable. For example, there is an attempt to commit the smuggling offense under article 270 para. 1 of Law no. 86/2006 when an individual does not succeed to introduce into the country tobacco products through places other than those established for customs control, being caught by the authorities. Also, there is an attempt to commit the smuggling offence under article 270 para. 3 of Law no. 86/2006 if an individual is trying to transport or sell tobacco products to the final consumer but is caught in the process.

\subsubsection{Law No. 227/2015 Regarding the Romanian Tax Code}

Article 452 of Law no. 227/2015 covers different behaviours that can be related to the illicit trade/smuggling of tobacco products. According to article 452 the following deeds are considered to be an offense:

- the production of excise goods covered by the warehousing procedure outside a fiscal warehouse authorized by the competent authority;

- the marking with falsified marks of the excisable products subject to the marking or the possessing in the fiscal warehouse of the marked products;

- the refusal to offer access to the competent authorities with control duties to performing unannounced checks in the fiscal warehouses;

- the possession outside the fiscal warehouse or sale on Romanian territory of excisable products subject to marking without being marked or badly marked or with false markings above the limit of 10,000 cigarettes, 400 cigarettes of $3 \mathrm{~g}$, 200 cigarettes of more than $3 \mathrm{~g}$ or over $1 \mathrm{~kg}$ of smoking tobacco.

In a Court decision it was held that the defendant produced during December 2016 until January 2017, outside the authorized fiscal warehouse, respectively in the building located in Bucov, Prahova county, the quantity of 38,740 cigarettes, which he intended to transport in other counties with the purpose of selling the products for the amount of 5 lei/pack of 20 cigarettes and 25 lei/box of 200 cigarettes. ${ }^{17}$

\subsubsection{Law No. 241/2005 on Tax Evasion}

Article 7 para. 1 of Law no. 241/2005 makes it an offense to place into circulation, without right, the stamps, banders or standardized forms used in the tax field, with a special regime. It is also an offense to knowingly print, use, possess or put into

no. 3009/2013; Suceava Court of Appeal, criminal section, decision no. 245/2012. www.sintact.ro/ \#/jurisprudence/528076833/1/decizie-nr-245-2012-din-12-mar-2012-curtea-de-apel-suceavainfractiuni-la-regimul-vamal-legea-141...? $\mathrm{cm}=$ SREST). Last accessed on 18 April 2020.

${ }^{17}$ See Ploiești Court of Appeal, criminal section, decision no. 1197/2017. www.rolii.ro/hotarari/ 5a0e4ecae49009f824000042. Last accessed on 20 April 2020. 
circulation of falsified stamps, banders or standardized forms, used in the tax field [art. 7 para. 2].

This offense is relevant in regard to illicit trade/smuggling of tobacco products because the deeds stipulated under article 270 of Law no. 86/2006 (see above) can be committed using falsified stamps in order to hide the origin of the tobacco products.

\subsection{Substantive Law Issues: Administrative Law}

We must emphasize that in the Romanian legislation there are many — and variedadministrative fines relevant for the illicit trafficking in tobacco.

\subsubsection{Government Decision No. 707/2006 for the Approval of the Regulation in Regard to the Application of the Customs Code of Romania}

Article 651 of Government Decision no. 707/2006 stipulates that the following deeds are punishable by an administrative fine of 500 lei (cc. 100 euro) to 1500 lei (cc. 400 euro):

- failure by the carrier [transporter - note] or his representative to fulfil the obligation to submit to the border customs office the accompanying documents of the means of transport engaged in international traffic and the documents regarding the goods transported with them;

- failure by the master, shipowner or agent of the ship to submit a statement of ship's stores within the time limits;

- failure by the postal authorities to declare and submit to the customs authority parcels and postal items which, according to the law, are subject to customs control;

- non-fulfilment by the postal bodies of the obligation to present the list of postal bags to the border customs office;

- failure by the carrier, at the request of the customs authority, to present the documents related to the means of transport for the goods transported in international traffic;

- non-compliance by any person with the obligation to make the customs authorities designated by the customs authority available to customs control;

- the transfer of the goods which have been the subject of a summary declaration in other cases and places than those established by the customs authority;

- failure by the owner of the commercial operation or his representative to oblige to apply within the legal term for the goods entered in the summary declaration, a customs destination; 
- non-fulfilment of the obligation to ensure the integrity of the seals or markings by the carrier or the unsecured operator, except in case of force majeure or force majeure;

- non-compliance by the holder of a mandatory information with the obligation to declare to the customs authorities, when carrying out customs formalities, that he is in possession of mandatory information relating to the goods in question;

- non-fulfilment by the holder of an authorization issued by the National Customs Authority of the obligation to notify the customs authority of any change after its granting;

- the lodging of a customs declaration containing incomplete or inaccurate data where this does not affect the determination of import duties and other legally owed duties representing taxes and duties to be imposed when goods are released for free circulation but which has effects on the application of the measures trade policy or other provisions established by special regulations.

Article 652 of Government Decision no. 707/2006 stipulates that the following deeds are considered to be a contravention punishable by a fine of 1500 lei (cc. 400 euro) to 3000 lei (cc. 700 euro):

- the failure by the transport manager to fulfil the obligation to stop at the specific formal signal of the authorized customs personnel;

- the mooring of ships or the landing of aircraft at places other than the control points where the customs authority operates, except in the event of force majeure, force majeure or serious illness on board;

- the failure to present documents of any kind and any support requested in the framework of customs control, as well as non-observance of the deadline established by the customs authority for the submission of documents;

- the non-fulfilment by natural persons crossing the border of the obligation to declare and present for the customs control the goods for which this obligation is stipulated;

- the provision by an applicant of erroneous or incomplete information on the basis of which a decision favourable to him was adopted by the customs authority;

- the exercise of any commercial, industrial or service activity in a free zone, free warehouse or free port, without complying with the conditions laid down in customs regulations and without prior notification by the customs authority;

- the transfer of the rights and obligations of the holder of an economic regime to other persons who do not fulfil the conditions laid down in order to benefit from the regime in question.

Article 653 of Government Decision no. 707/2006 stipulates that the following deeds are considered to be a contravention punishable by a fine of 3000 lei (cc. 700 euro) to 8000 lei (cc. 1700 euro):

- the removal from customs control of any goods or merchandize which are to be placed under a customs procedure. In this case, the goods are confiscated;

- unloading from ships, loading on ships or transhipment of goods or merchandize subject to customs clearance without customs clearance or without the consent of 
the customs authority; in this case the quantity of goods loaded, unloaded or transhipped shall be confiscated;

- the submission of the customs declaration and proof of origin containing erroneous data on the origin of the goods;

- the lodging of the customs declaration and accompanying documents containing incomplete or incorrect data on the customs value of the goods or merchandise;

- filing the customs declaration and accompanying documents containing erroneous data on the quantity of the goods if the act does not constitute an offense under the Customs Code. Where the determination of import duties and other legally owed duties representing taxes and duties to be charged by the customs authority on release for free circulation of goods is affected, the goods found in addition to those entered in the customs declaration shall be seized;

- exercising the activity of commissioner in customs without authorization; revenue from unauthorized activity is seized;

- filing the customs declaration and accompanying documents containing erroneous data on the type of goods. If this fact is influenced by the establishment of import duties and other legally owed duties representing taxes and duties to be charged by the customs authority when goods are released for free circulation, the goods found in addition to those entered in the customs declaration shall confiscate. The type of goods means the variety, type or those defining characteristics.

- non-fulfilment by the natural persons crossing the border of the obligation stipulated in art. 3 of Regulation (EC) No. 1.889/2005 of the European Parliament and of the Council declaring in writing to the Customs Authority the cash in foreign currency and/or national currency equal to or exceeding the limit set by the Regulation in their means of transport or in luggage accompanied or unaccompanied, as well as in parcels. Any unrecognized cash in excess of the limit set by the Regulation shall be confiscated.

If the deeds provided in art. 653 letter (a)-(c), where the goods are no longer identifiable, the offender shall be obliged to pay an amount equal to their customs value, to which shall be added the import duties and other legally owed duties representing taxes and duties fixed at the release for free circulation of the goods.

This measure has the same legal effect as the seizing of goods in respect of the extinction of the customs debt.

Article $653^{1}$ of Government Decision no. 707/2006 stipulates that if the deeds provided for in art. 651-653 are perpetrated by using modified means of transport for the purpose of dissimulation of goods or merchandize, the customs authority has, in addition to the other sanctions provided for contravention in question, the possibility to seize the modified means of transport.

Because at least some of the deeds provided under articles $651-653$ of the Government Decision no 707/2006 can also constitute an offense, art. 655 stipulates that a contravention is applicable only if the deed in question is not committed in such a way as to constitute, under criminal law, an offense. This is a subsidiarity clause that is problematic taking into consideration the ultima ratio principle. 


\subsubsection{Law No. 227/2015 on Tax Code}

Article 449 of Law no. 227/2015 provides that the retail sale excisable products from the fiscal warehouse, with the exceptions provided by the law, according to art. 362 par. (6) (the exceptions concern alcoholic beverages, beer, etc.) is to be considered a contravention unless it can also be considered an offense.

According to article 362 the production, processing and possession of excise goods, where the excise duty has not been levied, is allowed only in a fiscal warehouse. Any exception from this rule can only be provided by the law. It is forbidden to possess an excisable product outside the fiscal warehouse if the excise duty on that product has not been levied. Possession of excisable products outside the fiscal warehouse, for which no proof of excise duty can be obtained, entails the obligation to pay them.

According to article 367 any authorized warehouse keeper must submit to the competent authority, by the 15th of the month following the reporting date, the reporting situations provided for in the methodological norms. If the warehouse keeper fails to comply such a deed constitutes a contravention. A similar provision exists for the registered consignee-article 375 of Law no. 227/2015.

Also, article 449 provides that the following deeds constitute a contravention:

- failure to notify the competent authority in the case of deterioration of the seals applied according to the law;

- the carriage of excise goods under suspension of excise duty which is not covered by the electronic administrative document or, where applicable, by another document used for the procedure provided by the law, or by non-compliance with the procedure if the computerized system is unavailable to the expedition according to the tax law provisions;

- possession for commercial purposes, by failing to fulfil the condition provided by the law in regard to excise goods which have already been released for consumption in another Member State.

Another contravention is found in article 414 of Law no. 227/2015 which covers possessing outside the fiscal warehouse or the selling on the territory of Romania the excisable products subject to marking, without being marked or marked inappropriately or with false markings, as well as carrying out the wholesale trading of alcoholic beverages and manufactured tobacco.

\subsubsection{Law No. 12/1990 on the Protection of the Population Against Illicit Production, Trade and Services}

Article 1 of Law no. 12/1990 stipulates that it constitutes illicit commercial activities and constitute a contravention or can raise criminal liability, as the case may be, to those who have performed activities of production, trade or provision of services, as the case may be, with goods whose provenance is not proven, according to the law. 
Documents of origin must accompany the goods, no matter where they are, during transport, storage or sale. Documents of origin means, as appropriate, the tax invoice, the invoice, the consignment note, the customs documents, the external invoice or any other documents established by law.

\subsubsection{Fiscal Responsibility for Illicit Trade}

From the fiscal point of view, such a responsibility refers to the customs debt and the excise duties.

In regard to the customs debt, it consists in the amount of money needed to pay for the import or export duties. It becomes relevant when goods are being imported: (i) by illegally introducing the goods subject to import duties on the Romanian customs territory. It is also considered an illegal introduction if they are taken out of a free zone or free warehouse located on the territory of Romania; (ii) by non-fulfilment of one of the obligations which results, in regard to goods which are subject to import duties, from their temporary storage or from the use of their customs regime under which they are placed; (iii) by the consumption or use in a free zone or free warehouse of goods subject to import duties, in other conditions than those provided by the law.

It becomes relevant when goods are being exported by removing the goods subject to export duties from the customs territory of Romania without a customs declaration; or by failing to comply with the conditions under which goods were allowed to leave the customs territory of Romania with total or partial relief from export duties.

When goods are being imported, the following individuals are liable to pay the customs debt:

- the person illegally entering the goods in question;

- any person who participated in the illegal introduction of the goods and who knew or ought to have known that such an introduction was illegal;

- any person who bought or owned the goods in question and who knew or ought to have known, when purchasing or receiving the goods, that they had been illegally introduced.

- the person who stole the goods under customs supervision;

- any person who participated in such a deed and who knew or ought to have known that the goods had been taken out of customs supervision;

- any person who bought or held the goods in question and who knew or ought to have known, at the time of purchase or receipt of the goods, that they had been removed from customs supervision;

- the person who is required to fulfil his obligations with regard to goods subject to import duties following their temporary storage or use of the customs procedure under which they were placed;

- the person who was required to comply with the conditions governing the placement of goods under that regime. 
- the person who consumed or used the goods and any person who participated in such consumption or use and who knew or ought to have known that the goods had been consumed or used under conditions other than those provided for by law.

On the other hand, when goods are being exported, the customs duties are to be paid by: (i) the person who removed the goods and any person who participated and who knew or ought to have known that no customs declaration had been filed, although this should have been lodged at the customs authorities; (ii) in the event of non-compliance with the conditions under which the removal of the goods was allowed, the debtor is the declarant. In the case of indirect representation, the person on whose behalf the declaration is made is also a debtor; (iii) the amount of the customs debt shall be determined on the basis of the chargeable elements from the time a customs debt started to exist. The moment of the customs debt is the moment when the goods are illegally introduced/removed or when an equivalent fact takes place. Compensatory interest may be applied in order to avoid a financial gain by postponing the date of birth of the customs debt or entry in the accounts and the cases and conditions under which it is applicable shall be determined by the customs regulation.

Excise goods (manufactured tobacco) are subject to excise duty at the time of their production, including or when they are imported into the territory of the European Union. Such goods become chargeable at the time of release for consumption. The conditions of chargeability and the level of excise duty applicable shall be those in force on the date on which the excise duty becomes chargeable in the Member State in which the release for consumption takes place.

The release for consumption is considered to be:

- the exit of excise goods, including an irregular one, from a suspensive regime of excise duties;

- the possession of excise goods outside a suspensive regime of excise duty for which excise duty has not been levied;

- the production of excisable products, including with irregularities, outside a suspensive regime of excise duties;

- the importation of excise goods, including with irregularities, except where excise goods are placed, immediately after import, under a duty suspension arrangement;

- the use of excisable products inside the fiscal warehouse other than as raw material.

- the commercial possession by a person of excise goods which have been released for consumption in another Member State and for which excise duty has not been collected in Romania.

- in the case of an excise goods for which the excise duty was not previously due, release shall be considered for consumption when the excise goods are held in a fiscal warehouse for which the authorization was revoked or cancelled.

- in the case of an excise goods for which the excise duty was not previously due, release shall be deemed to be release for consumption when the excise product is 
held in a fiscal warehouse for which the authorization has expired and a new authorization has not been issued.

- in the case of an excise product entitled to be exempted or exempt from excise duty, use for any purpose not in accordance with the exemption, that is to say, the exemption entails the obligation to pay the excise duty.

In principle, the individuals responsible for committing offenses or contraventions are also liable to pay excise duties. In regard to the exit of excise goods from a suspensive arrangement of excise duty, the person responsible is the authorized warehouse keeper, the registered consignee or any other person who issues the excise goods under the excise duty suspension arrangement or on whose behalf such release is made and, in the event of an irregular departure from the fiscal warehouse, any other person who participated in that exit. In the event of an irregularity in the course of a movement of excise goods under a duty suspension arrangement, as defined in Art. 412 par. (1), (2) and (4) of the Tax Code, the person responsible is the authorized warehouse keeper, the registered consignor or any other person who has guaranteed excise duty in accordance with art. 348 par. (1) and (2) of the Tax Code, as well as any person who participated in the irregular departure and who was or would have been aware of the irregular nature of such an exit;

In regard to the possession of excise goods, the person who possess the excise goods or any other person involved in their possession.

In regard to the production of excise goods, the person who produces the excise goods or, in the case of unauthorized production, any other person involved in their production;

In regard to the import of excise goods, the person who declares the excise goods or on whose behalf the products are declared at the time of import or, in the case of irregularities to the import, any other person involved in their import;

When more than one person is required to pay the same excise duty, they are required to pay that debt jointly and each of these people can be tracked for the entire debt.

We also must emphasize that IQOS or electronic cigarette products are due to non-amortized excises (see Articles 439-441 of the Tax Code).

\subsection{Relation Between Criminal and Administrative/Fiscal Responsibility}

The fact that the participant in the offense is liable to pay the customs debt and the excise duties does not raise problems from the perspective of the ne bis in idem principle, because in such a context it is considered a reparation and not a criminal sanction.

The ne bis in idem principle is applicable only in situations where the same deed is punished both as a contravention (administrative fine) and as a criminal offense (criminal fine or imprisonment). 
However, the legislator attempted to resolve such an overlap by imposing a series of obligations in behalf of the authorities. More specifically, by Government Ordinance no. 2/2001, it established the following (see article 30): If the person empowered to impose the sanction considers that the deed was committed under such conditions as to constitute a criminal offense, according to the criminal law, it shall notify the competent prosecution body [Article 30 par. (1)]. Taken into consideration this provision, the custom authorities will not impose an administrative/ fiscal liability if the deed in question also consists in a criminal offense. But if the custom authorities impose an administrative sanction for a particular deed, no criminal liability can raise for the same deed.

Article 30 also provides that if the act was prosecuted as an offense and subsequently it was determined by the prosecutor or the court that it could constitute a contravention, the act of notification or the finding of the deed, together with a copy of the resolution, the ordinance or, as the case may be, from the court order, the law body shall be immediately informed of the offense, in order to take the necessary measures according to the law.

\subsection{Relations Between Criminalisation of Illicit Trade of Tobacco and Other Types of Economic Crimes}

Because there are many overlaps between different criminal provisions relevant in the context of illicit trade of tobacco products, it must be established if different offenses can be committed in concurrence or not.

\subsubsection{The Relationship Between the Smuggling Offense (Article 270 (3) of Law No. 86/2006 on the Customs Code of Romania) and the Offense Provided by Article 452 Letter d) of Law No. 227/2015 (Tax Code)}

The relationship between art. 270 para. (3) of Law no. 86/2006 and art. 452 letter d) of Law no. 227/2015 was clarified by the High Court of Cassation of Justice [Înalta Curte de Casaţie și Justiţie] after different points of view emerged in the jurisprudence.

By a preliminary judgement, namely by Decision no. $17 / 2013^{18}$ (published in the Official Gazette, Part I no. 35 of 16.01.2014) the High Court of Cassation and Justice concluded that the act of possessing excisable goods subject to marking, without marking, or marked inappropriately, outside the tax warehouse, knowing that they come from smuggling, constitutes only the offense provided by art. 270 para. (3) of

\footnotetext{
${ }^{18}$ Available at the following link: www.scj.ro/1093/Detalii-jurisprudenta?customQuery\%5B0\%5D. $\mathrm{Key}=\mathrm{id} \&$ customQuery\%5B0\%5D.Value $=86231$. Last accessed on 15 April 2020.
} 
Law 86/2006 on the Customs Code of Romania. We must emphasize that a preliminary judgement from the High Court of Cassation and Justice is mandatory for the courts.

Basically, the High Court of Cassation and Justice stated that the offense provided under art. 270 para. (3) of Law no. 86/2006 has a complex nature and it includes also the deed provided by art. 452 letter d) of Law no. 227/2015.

\subsubsection{The Relationship Between the Smuggling Offense (Article 270 of Law No. 86/2006) and the Offense of Tax Evasion (Article 9 Para. 1 of Law No. 241/2005)}

The High Court of Cassation and Justice stated in decision no. 1145/2013 that the possession and transport of goods or merchandize to be placed under a customs procedure such as cigarettes, knowing that they come from smuggling for the purposes of sale without payment of customs duties, excise duties and value added tax [VAT], by removing them from the payment of their obligations tax, is covered by the offense provided in art. 270 par. (3) of the Law no. 86/2006, and not the elements of the offense of tax evasion provided in art. 9 par. (1) lit. a) of Law no. 241/2005. The rationale of the court emphasized the fact that the offense provided under Art. 270 para. (3) of the Law no. 86/2006 consists in a specific deed of avoiding the payment of tax liabilities of goods or goods illegally introduced into the country.

\subsubsection{The Relationship Between the Smuggling Offense (Article 270 of Law No. 86/2006) and the Money Laundering Offense (Article 49 Para. 1 c) of Law No. 129/2019)}

The relationship between the two offenses raises problems from the perspective of para. (3) of art. 270 of Law no. 86/2006, which states that the deeds of collecting, possessing, producing, transporting, taking over, storing, handing over, disposing of and selling the goods or merchandise to be placed under a customs procedure knowing that they are smuggled or intended to be smuggled are assimilated to the smuggling offense and are punished according to par. (1).

The relationship between the two is solved according to the rule of special normgeneral norm. Para. (3) of article 270 of Law no. 86/2000 would be the special norm, and article 49 para. (1) c) of Law no. 129/2019 would be the general norm. Also, according to article 49 para. (1) c) of Law no. 129/2019 the deed of acquisition, possession or use of goods must be perpetrated by another person than the one committing the offense from which the goods are originating. In other words, the person who commits a smuggling offense cannot be found criminal liable also for a money laundering offense, in regard to the same goods. The narrow scope of the mentioned money laundering offense is due to Decision no. 625/2018 of the Constitutional Court. 


\subsubsection{The Relationship Between the Smuggling Offense (Article 270 of Law No. 86/2006) and Organized Crime Offense (Article 367 of the Criminal Code)}

According to article 367 para. 6 of the Criminal Code an "organized criminal group" means a structured group, made up of three or more persons, which exists for a certain period of time and acts in a coordinated manner for the purpose of perpetrating one or more offenses. The criminal offense stipulated under article 367 of the Criminal Code consists is a deed of initiating or creating an organized crime group or of joining or supporting such a group in any way.

If the smuggling offense was committed by an organized criminal group, both offenses will be taken into consideration as a concurrence of offenses. A problem arises in such a context because of the aggravated circumstance of the offense provided by art. 274 of Law no. 86/2006 - when the smuggling is perpetrated by two or more individuals together. The legal literature, in relation to the relationship between the general aggravating circumstance-committing the deed by three or more individuals together-and the offense of an organized criminal group, it was stated that although the aggravating circumstance could not be held altogether with the offense of an organised criminal group, such a restriction does not apply for offenses committed by the group.

The same conclusion was reached in the jurisprudence regarding the relationship between the aggravated form of the smuggling offense (Article 274 of Law no. 86/2006) and the offense of an organized criminal group, namely that both of them are applicable. ${ }^{19}$

\subsubsection{The Relationship Between Illicit Trade of Tobacco and Corruption}

If the illicit trade of tobacco products includes bribery (art. 290 of the Criminal Code) or an act of influence peddling (art. 292 of the Criminal Code) there will be a concurrence of offenses. The basic argument for such a solution is that any offense in regard to corruption protects a completely different social good than the one protected by an offense that covers the deed of illicit trade of tobacco.

\footnotetext{
${ }^{19}$ See High Court of Cassation and Justice, criminal section, decision no. 129/2016. www.scj.ro. Last accessed on 20 April 2020; High Court of Cassation and Justice, criminal section, decision no. 146/2016. www.scj.ro. Last accessed on 19 April 2020; Timişoara Court of Appeal, criminal section, decision no. 1071/2019. www.rolii.ro/hotarari/5dc4d81de490098019000031. Last accessed on 20 April 2020; Oradea Court of Appeal, criminal section, decision no. 141/A/2017. www.rolii.ro/hotarari/58d6790de49009f41b00003a. Last accessed on 20 April 2020; Galați Court of Appeal, criminal section, decision no. 477/A/2016. www.rolii.ro/hotarari/ 5898bbd1e490095834001a4c. Last accessed on 20 April 2020.
} 
Relevant in this contest is a decision from Oradea Court of Appeal ${ }^{20}$ in which the Court concluded that the defendants asked the Ukrainian citizens to illegally introduce cigarettes in Romania and communicated the date, time and location by which they were going to do so, with one of the defendants waiting for them in that place. It also turned out that one of the defendants repeatedly contacted a border police officer and offered him money for not fulfilling his duties.

In this context it must be emphasized that two of the first, biggest and most notorious corruption scandals in Romania were related to the illicit trade of tobacco. These cases were named by the media "Cigarette 1" and "Cigarette 2".

"Cigarette 1" broke out in the media in 1993 when in a warehouse belonging to the Romanian Armed Forces were discovered cases of cigarettes, which were smuggled across Romanian borders. The cigarettes were delivered by a contractual partner of Romtehnica (Romanian company in National Defence Industry), allegedly as a partly payment for weaponry delivered by Romtehnica. Members of the Armed Forces were convicted, including the general director of Romtehnica.

"Cigarette 2" first appeared in the media in April 1998. Two Romanian newspapers received an anonymous information about a Ukrainian plane landing on Otopeni Military Airport, caring on board 4275 master cases of smuggled cigarettes. There were 19 people indicted, out of which 15 convicted, including members of the Romanian Armed Forces and of the Romanian Protection and Guard Service (secret service, with tasks in the field of national security).

\subsubsection{The Relationship Between Illicit Trade of Tobacco and Organised Crime}

In this context the relevant the offense is the one provided by article 367 of the Criminal Code which stipulates the following:

(1) The act of initiating or creating an organized criminal group or of joining or supporting such a group in any way shall be punishable by no less than 1 and no more than 5 years of imprisonment and a ban on the exercise of certain rights.

(2) When the offenses included in the purpose of an organized crime group are punished by life imprisonment or by a term of imprisonment exceeding 10 years, it shall be punishable by no less than 3 and no more than 10 years of imprisonment and a ban on the exercise of certain rights.

(3) If the acts set out in par. (1) and par. (2) were followed by the commission of an offense, the rules on multiple offenses shall apply.

(4) No penalty shall apply to the individuals who committed the acts set out in par. (1) and par. (2) if they report the organized crime group to the authorities before it was discovered and before the commission of any of the offenses included in the purpose of the group.

(5) If the perpetrator of one of the acts referred to in par. (1) - (3) facilitates, during the criminal investigation, discovery of the truth and the prosecution of one of more

\footnotetext{
${ }^{20}$ See Oradea Court of Appeal, criminal section, decision no. 430/2015. www.rolii.ro/hotarari/ 589a3734e49009742f001c3f. Last accessed on 20 April 2020.
} 
members of the organized crime group, the special limits of the penalty are reduced by one-half.

(6) An "organized crime group" means a structured group, made up of three or more persons, which exists for a certain period of time and acts in a coordinated manner for the purpose of perpetrating one or more offenses.

Taken into consideration article 367 para. 3 of the Criminal Code, if a person initiates, creates, joins or supports in any way an organized criminal group and such criminal deeds are then followed by the commission of a smuggling offense, such a person will be found criminal liable for both offenses (see above).

\subsection{Sanctions}

\subsubsection{Aggravating Circumstances}

In this context is relevant the aggravating circumstance provided by art. 274 of Law no. $86 / 2006$ - the smuggling is committed by two or more persons together. If the smuggling offense provided by article 270 of Law no. 86/2006 is committed in this aggravating circumstance then the criminal sanction is imprisonment from 5 to 15 years and the prohibition of certain rights.

Regarding the situation in which the criminal activity meets the elements of multiple offenses, the criminal sanctions will be merged according to article 39 of the Criminal Code: when only penalties of imprisonment have been established, the heaviest penalty shall be applied, which can be increased by one-third of the total of all the other penalties handed down.

In regard to contraventions (administrative fines) both negligence and intention can raise liability. No strict liability is allowed by the law in the context of contraventions but negligence is sufficient to raise liability.

In regard to all the offenses which covers illicit trade or smuggling of tobacco products it must be emphasized that liability can only be raised if the prosecution can prove the intent to commit the criminal deed in question. The intent can be a direct one or an indirect one (dolus eventualis).

\subsubsection{Sanctions Applicable for Illicit Trade of Tobacco Products with Regard to Individuals}

The basic form of the smuggling offence [see article 270 of Law no. 86/2006] is punishable by 2 to 7 years of imprisonment and the aggravating form [see article 274 of Law no. 86/2006] is punishable by 5 to 15 years of imprisonment. In the Tax Code (Law no. 227/2015), for certain deeds the punishment is imprisonment from 1 to 5 years [e.g. Article 452 para. 1 letters e) and h)], for the other offenses being between 2 and 7 years. 
In our research we have found that for the offence provided under art. 270 parag. 3 of Law no. 86/2006 (collecting, possessing, producing, transporting, taking over, storing, handing over, disposing of and selling the goods or merchandise to be placed under a customs procedure knowing that they are smuggled or intended to be smuggled), if the quantity of the smuggled goods is relatively low, a minimum imprisonment punishment is the most common penalty, the sentence being suspended. In contrast, in cases were the offenses are committed by an organized criminal group the sentence it is not suspended, and the courts tend to establish punishments close to the statutory maximum. Still, it must be emphasized that there is no available data in regard to the penalties applied by the courts for criminal offenses relating to illicit trade.

The prohibition of certain rights-this constitutes a complementary [ancillary]/ accessory criminal sanction, that is mandatory in the case of the offenses provided by Law no. 86/2006 [regarding smuggling] and Law no. 241/2005 [regarding tax evasion], except for the ones provided by the Tax Code.

According to article 66 of the Criminal Code complementary [ancillary] penalty consists in a ban, for one to five years, on the exercise of one or several of the following rights:

a) right to be elected to the ranks of public authorities or any other public office;

b) right to take a position that involves exercise of State authority;

c) right of a foreign citizen to reside on Romanian territory;

d) right to vote;

e) parental rights;

f) right to be a legal guardian or curator;

g) the right to take the position, exercise the profession or perform the activity they used in order to commit the offense;

h) the right to own, carry and use any category of weapons;

i) the right to drive certain categories of vehicles as established by the Court;

j) the right to leave Romanian territory;

k) the right to take a managerial position with a public legal entity;

l) the right to be in certain localities as established by the Court;

$\mathrm{m})$ the right to be in certain locations or attend certain sports events, cultural events or public gatherings, as established by the Court;

n) the right to communicate with the victim or the victim's family, with the persons together with whom they committed the offense or with other persons as established by the Court, or the right to go near such persons;

o) the right to go near the domicile, workplace, school or other locations where the victim carries social activities, in the conditions established by the Court.

Both for contraventions and offenses, confiscation [seizing] is mandatory. Regarding to this subject there is also a preliminary judgement of the High Court of Cassation and Justice (decision no. 11/2015) in which it was stated that in the case of the smuggling offense provided by Law no. 86/2006 on the Customs Code of Romania, it is necessary to apply the criminal provisions on special confiscation of the goods or merchandize illegally entered in the customs territory of Romania, at the 
same time as obliging the defendants to pay the amounts representing the customs debt only if they have passed the first customs office located in the customs territory of the Community without having been presented to customs and transported to that customs office.

Also, according to article 449 para. 3 of Law no. 227/2015, in case of a criminal deed that has the nature of a contravention, without making a difference between the individual or the legal entity (although some measures are applicable only to legal entities), the following measures are provided:

a) the confiscation of the products and, if sold, confiscation of the proceeds of the sale,

b) seizure of tanks, containers and means of transport used in the transport of excise goods

c) suspension of trading of excisable products for a period of 1-3 months in the case of wholesale and/or wholesale traders;

d) stopping the production of excisable products by sealing the plant, in the case of producers;

e) suspension, upon proposal of the control body, of the fiscal warehouse permit, registered consignee, registered consignor or authorized importer, as the case may be, for the situations stipulated in paragraph (1) lit. j) and par. (2) lit. g) and $\mathrm{m}$ ).

f) the revocation, on the proposal of the control body, of the fiscal warehouse permit, registered consignee, registered consignor or authorized importer, as the case may be, for the situations stipulated in paragraph (1) lit. b), d) and e).

g) also, the competent control body may order the stopping of the activity, the sealing of the plant in accordance with the technological closure procedures of the plant and the submission of the control act to the tax authority that issued the authorization with the proposal to suspend the fiscal warehouse authorization.

\subsection{Legal Responsibility of Legal Entities}

According to article 135 of the Criminal Code a legal entity can be found criminal liable under following conditions: if the offense is being committed in the performance of the object of activity of legal entities or in their interest or behalf (article 135 para. 1 of the Criminal Code). For example, this criminal provision could apply if a legal entity that sells tobacco products starts to sell or transport smuggled tobacco products.

The criminal liability of legal entities does not exclude the criminal liability of the individual participating in the commission of the criminal deed. For example, in a 
decision from the Craiova Court of Appeal ${ }^{21}$ it was also held that the defendant is the owner of an Individual Enterprise, whose main activity is retail trade in non-specialized stores, with a predominant sale of food, beverages and tobacco. Considering that the defendant collected and detained cigarettes and alcoholic beverages, in accomplishing the object of activity of the legal entity, it was found that the Individual Enterprise is also guilty of the offense provided under article 270 para. (3) of Law no. 86/2006.

It must be emphasized that in our research we have identified very few cases in which legal entities were convicted for criminal offenses related to illicit trade of tobacco. Also, there is not any official data available in this regard. Still, this does not mean that a legal entity cannot be found criminal liable for any of the offenses which covers illicit trade of tobacco products.

In the case of an offense, the principal, complementary and accessory criminal sanctions are provided by article 136 of the Criminal Code, as well as the confiscation measure.

In the case of the offenses provided by the Tax Code (Law no. 227/2015), after the facts have been established, the competent control body may order the closure of the activity, the sealing of the plant in accordance with the technological closure procedures of the installation and the forwarding of the control act to the tax authority that issued the permit, to suspend the tax warehouse authorization.

According to article 136 of the Criminal Code, the criminal sanctions applicable to legal entities can consist in a criminal fine and different complementary (ancillary) penalties. The main penalty that can be imposed to a legal entity is a criminal fine, which is the sum of money that the legal entity is ordered to pay to the State. The criminal fine is established according to article 137 of the Criminal Code. The amount of the fine is determined based on the fine-days system. The amount corresponding to the fine-days, varying between Lei 100 and 5000, shall be multiplied by the number of days subject to the fine (between 30 and 600 days). The court shall decide on the number of days subject to the fine considering the general criteria for the customization of penalty. The amount of the fine-days is determined by taking into account the turnover (in case of for-profit legal entities), and the value of assets (in case of the other legal entities), as well as other obligations of the legal entity.

When the offense committed by legal entity was intended to the obtaining of a monetary benefit, the special limits of the fine-days provided by law for the committed offense may be increased by one-third, without exceeding the general maximum of the fine. When determining the fine, the value of the monetary benefit obtained or sought shall be considered.

The complementary (ancillary) penalties consists in the following:

\footnotetext{
${ }^{21}$ See Craiova Court of Appeal, criminal section, decision no. 333/2013. www.sintact.ro/\#/jurispru dence/526739783/1/decizie-penala-nr-333-2013-din-18-feb-2013-curtea-de-apel-craiovainfractiuni-la-regimul-vamal...?cm=SREST. Last accessed on 13 April 2020.
} 
- winding-up of legal entities;

- suspension of the activity or of one of the activities performed by the legal entity, for a term between three months and three years;

- closure of working points of the legal entity for a term between three months and three years;

- prohibition to participate in public procurement procedures for a term between one and three years;

- placement under judicial supervision;

- display or publication of the conviction sentence.

In the case of contraventions, the sanction is an administrative fine. Other measures may also be taken, such as: the confiscation of the products and, if sold, confiscation of the proceeds of the sale; the seizure of tanks, containers and means of transport used in the transport of excise goods; the suspension of trading of excisable products for a period of 1-3 months in the case of wholesale and/or wholesale traders; the stopping the production of excisable products by sealing the plant, in the case of producers; suspension, upon proposal of the control body, of the fiscal warehouse permit, registered consignee, registered consignor or authorized importer, as the case may be, for the situations stipulated in paragraph (1) lit. j) and par. (2) lit. $\mathrm{g}$ ) and $\mathrm{m}$ ); the revocation, at the proposal of the inspection body, of the fiscal warehouse permit, registered consignee, registered expeditor or authorized importer, as the case may be, for the situations stipulated in paragraph (1) lit. b), d) and e).

The competent control body may also discontinue the activity, sealing the plant in accordance with the technological closure procedures of the installation and submitting the control act to the tax authority that issued the permit with the proposal to suspend the fiscal warehouse permit.

\subsection{Disposal or Destruction of Confiscated Tobacco Products}

The Customs Code (Law no. 86/2006) stipulates that the rules are laid down in a customs regulation, but there no reference in the customs regulations in force in regard to the destruction of goods.

The Tax Code (Law no. 227/2015) provides for the following under article 431:

(1) By way of derogation from the legal provisions in the field regulating the manner and conditions for the capitalization of assets legally seized or admitted, according to the law, private property of the state, processed tobacco seized or entered, according to the law, in the private property of the state, by the body which ordered confiscation, for destruction, authorized warehousekeepers, registered consignees or importers authorized by such products as follows:

(a) the varieties appearing in the product nomenclature of authorized warehousekeepers, registered consignees, registered consignors or authorized importers shall be surrendered in their entirety; 
Table 1 Assets recovery in relation to illicit trade of tabacco products

\begin{tabular}{l|l|l|l}
\hline Year & 2017 & 2018 & 2019 \\
\hline $\begin{array}{l}\text { Quantity of seized } \\
\text { cigarettes }\end{array}$ & $149,097,768$ pcs. & $112,964,175$ pcs. & $137,833,307$ pcs. \\
\hline $\begin{array}{l}\text { Total value of the } \\
\text { seized cigarettes }\end{array}$ & $\begin{array}{l}90,934,411 \text { lei } \\
\text { (cc. } 20 \text { million euros) }\end{array}$ & $\begin{array}{l}\text { 49,913,172 lei (cc. } 10.7 \\
\text { million euros) }\end{array}$ & $\begin{array}{l}71,753,182 \\
\text { (cc. 15 million } \\
\text { euros) }\end{array}$ \\
\hline
\end{tabular}

Source: www.stopcontrabanda.ro (The aggregate presented figures are from the official reports of the Romanian Police and the Border Police and from other official communications)

(b) the varieties which do not appear in the nomenclatures stipulated in letter a) are handed over to custodial authorities by authorized bodies for the production and/or storage of manufactured tobacco.

(2) The distribution of each batch of confiscated manufactured tobacco, the taking over of the manufactured tobacco by the authorized warehouse keepers, the registered consignees and the authorized importers, as well as the destruction procedure shall be performed according to the provisions of the methodological norms.

(3) Each authorized warehouse keeper, registered consignee and authorized importer shall ensure at his own expense the taking over, transporting and storing the quantities of products in the confiscated consignment which he has been assigned to.

\subsection{Asset Recovery Related to Illicit Trade of Tobacco Products}

There are no relevant statistics regarding assets recovery in relation to illicit trade of tobacco products. The only available relevant data refers to the number of seized cigarettes (Table 1).

\subsection{The Impact of the WTO FCTC and the 2012 Protocol to the FCTC on the National Law}

Romania ratified the Convention in 2005 by Law no. 332/2005. In regard to the 2012 Protocol, until now Romania has not ratified it. Even so, in 2016 the Romanian legislator adopted a law that would, in principle, constitute the implementation of the protocol.

It should also be emphasized that the European Union has made a statement on the Protocol, stating that aspects regarding its exclusive competence are adopted by the Protocol, and on the other matters it is up for the member states to decide.

The national legislation is at some extend in compliance with the provisions of the Protocol. In regard to behaviours considered to be illegal under the Protocol, they are 
also mostly considered to be illegal under the national law, being criminalized either as an offense or as a contravention.

The correspondence between the illicit deeds provided under art. 14 of the Protocol and the national legislation can be found in the table below.

(a) Manufacturing, wholesale, brokerage (acting as agent for others, such as negotiating contracts, purchases or sales, in exchange for a remuneration or a commission), selling, transporting, distributing, storing, shipping, importing or the export of tobacco, tobacco products or manufacturing equipment that contravenes the provisions of this Protocol (it is required, in principle, that persons involved in the distribution chain be authorized and comply with certain due diligence, in order to prevent illicit trade).
These acts under Romanian law would constitute either a criminal offense, either a contravention.

Offenses:

- art. 270, art. 272 and art. 273 from Law no. $86 / 2006$ (see the references made above, I.1).

- art. 452 from Law no. 227/2015 (Tax

Code) — the holding by any person outside the fiscal warehouse or the marketing on the territory of Romania of excisable products subject to marking, according to the present title, without being improperly marked or marked or with false markings above the limit of 10,000 cigarettes, 400 cigarettes of 3 grams, 200 sheet cigarettes larger than $3 \mathrm{~g}$, over $1 \mathrm{~kg}$ smoking tobacco, ethyl alcohol over 40 litters, spirits over 200 litters, intermediate products over 300 litters, fermented beverages, other than beer and wines, over 300 litters.

Contraventions (administrative fines):

-art. 652 letter g) from Ordinance no. 707/2006 for the approval of the Regulation applying the Romanian Customs Codetransfer of the rights and obligations of the holder of an economic customs regime to other persons who do not fulfil the conditions provided to benefit from the regime in question; - art. 449 para. (1) letter b) of Law no. 227/2015 (Tax code)_retail sale of excisable products from the fiscal warehouse; - art. 449 para. (2) of Law no. 227/2015 (Tax code). ${ }^{\mathrm{a}}$

- art. 1 of Law no. 12/1990

- art. 23 of Law no. 201/2016 contains provisions which would transpose the protocol regarding the track \& tracing system. Violations of the provisions in question are considered to be a contravention punishable by an administrative fine.

In conclusion, the distribution, storage, shipping etc. of manufacturing equipment are not covered by the legal provisions.

(b) (i) manufacture, wholesale, brokerage, sale, transport, distribution, storage, shipment, import or export of tobacco, tobacco products or manufacturing equipment without payment
In principle, the same texts as in the previous section and also art. 7 of Law 241/2005, which states that it is a criminal offense to possess or to put into circulation, without right, the 
of applicable taxes, taxes and other taxes or without the application of stamps tax, unique identification markings or any other necessary markings or labels;

(ii) any other acts of smuggling or attempted smuggling of tobacco, tobacco products or manufacturing equipment that are not covered by point (b) (i);

(c) (i) any other form of illicit manufacture of tobacco, tobacco products or tobacco manufacturing equipment or packaging bearing tax stamps, unique identification markings or any other necessary markings or labels forged; (ii) wholesale, brokerage, sale, transport, distribution, storage, shipment, import or export of illicitly manufactured tobacco, illicit tobacco products, products with tax stamps and/or other necessary markings or labels or counterfeit equipment; illicit manufacturing;

(d) mixing tobacco products with other types of products along the supply chain, in order to hide or hide tobacco products.

(e) mixing of tobacco products with other types of products, in violation of Article 12 (2) of this Protocol (mixing of tobacco products with other types of products in a single container or any other similar transport unit at the time is prohibited exit from free zones).

(f) using Internet-based sales methods, telecommunications or any other new technology for marketing tobacco products in violation of the Protocol (which imposes the same obligations as any other trader).

(g) obtaining by the holder of an authorization, in accordance with Article 6, tobacco, tobacco products or manufacturing equipment from a person who should hold an authorization in accordance with Article 6, but who does not hold such an authorization;

(h) obstruction of a public official or an authorized official in the performance of his duties related to the prevention, deterrence, detection, investigation or elimination of illicit trade in tobacco, tobacco products or manufacturing equipment;

(i) (i) any false, misleading or incomplete material statement or failure to provide the information requested by a public official or authorized officer in the performance of his or her duties related to the prevention, deterrence, stamps, banders or standardized forms used in the tax field, with a special regime and to knowingly print, use, possess or put into circulation falsified stamps, banders or standardized forms, used in the tax field.

These actions are not criminalised with regard to the manufacturing equipment.

These acts do not seem to be covered by the law, but they could be considered as a preparatory act in order to commit another offense.

These acts are covered by the law in the same way as a regular sale.

The person who does not have authorization would commit a crime (either smuggling or producing excisable products, incriminated by art. 452 Tax Code), consequently, it would be smuggling/stealing/money laundering. There are no incrimination rules in relation to manufacturing equipment.

It is incriminated both as an offense (art. 452 paragraph 1, letter e fiscal code), as well as a contravention by the Regulation applying the Romanian Customs Code (see Government decision no. 707/2006).

Such deeds are considered to be offenses under art. 272 and art. 273 of Law no. 86/2006, even if the traditional offenses regarding the forgery of documents could also apply. The contravention regime stipulated by the Regulation 
detection, investigation or elimination of illicit trade in tobacco, tobacco products or manufacturing equipment, when this does not contravene the right not to incriminate oneself; (ii) false statements made in official forms in relation to the description, quantity or value of tobacco, tobacco products or manufacturing equipment or any other information provided in the protocol for the purpose:

(a) to evade payment of the applicable taxes, duties and other charges; or

(b) to prejudice any control measures to prevent, deter, detect, investigate or eliminate the illicit trade in tobacco, tobacco products or manufacturing equipment;

(iii) refusal to set up or keep records covered by this Protocol or to keep false records;

(1) the laundering of the proceeds of illicit deed established as an offense under paragraph 2 applying the Romanian Customs Code also applies, when it comes to incorrect or inaccurate data. Also, by Law no. 201/2016 it is sanctioned as a contravention the violation of the provisions regarding the keeping of the records, in case such a behaviour does not constitute an offense.

${ }^{a}$ Article 449 para. (2) of Law no. 227/2015: "a) the sale by any person of cigarettes for which retail prices have not been established and declared according to art. 343 para. (9);b) the sale of cigarettes by any person at a price that exceeds the retail price declared according to art. 343 para. (10);c) the sale of cigarettes by any person to natural persons at a price lower than the retail price declared according to art. 343 para. (11);d) capitalization of excisable products in a fiscal warehouse for which the authorization has expired, has been revoked or cancelled, without payment of excises to the state budget, according to art. 344 para. (2);e) non-observance of the provisions of art. 356 paragraph (2) and art. 357;f) non-observance of the provisions of art. 362 para. (1) and (7);g) failure of the competent authority in case of deterioration of the seals applied according to art. 367 para. (1) lit. c);h) failure to comply with the provisions of art. 397 para. (3);i) the transport of excisable products under suspension of excise duty which is not covered by the electronic administrative document or, as the case may be, by another document used for this regime, provided for in this title, or with the failure to comply with the procedure if the computerized system is unavailable upon shipment according to the provisions of art. 402 paragraph (1) and art. 406 paragraph (1);j) holding for commercial purposes, failing to fulfil the condition provided in art. 414 para. (1), of excise goods that have already been released for consumption in another Member State;k) holding outside the fiscal warehouse or marketing on the territory of Romania excisable products subject to marking, according to the provisions of art. 421 para. (3), without being marked or improperly marked or with false markings below the limits provided in art. 452 para. (1) lit. h);l) non-observance of the provisions of art. 428 para. (3);m) non-observance of the provisions of art. 435 paragraph (1);n) non-observance of the provisions of art. 435 paragraph (2);o) carrying out the wholesale marketing of alcoholic beverages and processed tobacco and the wholesale and / or retail marketing of energy products - gasoline, diesel, lamp oil, liquefied petroleum gas, and biofuels, with non-compliance with the obligations set out in art. 435 paragraph (3) and (4);p) acquisition of excisable products from persons carrying out wholesale distribution and marketing activities of alcoholic beverages and processed tobacco, respectively wholesale marketing of energy products petrol, diesel, lamp oil and liquefied petroleum gas, as well as biofuels and non-fuels. respects the conditions or obligations provided in art. 435 paragraph (3) and (4)" 


\subsection{Procedural Law Issues}

\subsubsection{Institutional Framework}

In the case of offenses, the institutions involved would be criminal investigation bodies (police, including Border Police) and the Public Ministry-investigating offenses. The Directorate for Investigating Organized Crime and Terrorism [DIICOT], which is a specialized prosecution body attached to the High Court of Cassation and Justice prosecution body. If the offenses regarding the illicit trade of tobacco products are being committed by a criminal organization (defined by article 367 of the Criminal Code) DIICOT is the competent body for the criminal investigation in question (see in this regard article 11 from the OUG [Government Ordinance] no. 78/2016). Also, ANAF (National Agency for Fiscal Administration) is responsible for the recovery of the damage or the notification of the criminal investigation bodies. Secret services are not competent to investigate smuggling offenses, but may report to the criminal investigation bodies if they have relevant information.

In the case of contraventions, the competent authority to apply the sanction for contraventions established by the customs regulation is the customs authority [National Agency for Fiscal Administration and the subordinated structures], namely the person empowered by the customs authority. If the customs offenses are found by the police or other bodies responsible for control in places other than the premises of the customs and where operations are under customs supervision, they are required to present once documents attesting to the customs authority closest to the goods subject to the offense (Article 280 of Law no. 86/2006). In the case of contraventions provided by the Tax Code, the competent bodies within the Ministry of Public Finance, through ANAF [National Agency for Fiscal Administration], are found and sanctioned. and its subordinated units, except sanctions on the suspension or revocation of the authorization of tax warehouse, registered consignee, registered consignor or authorized importer, which has competent authority on the proposal of the control. For contravention stipulated by Law 12/1990, establishing offenses and penalties are carried out by officials from the mayor's specialized apparatus, Fiscal Antifraud Directorate General, financial control bodies and the staff of the Romanian Police and Police Romanian Border.

A cooperation protocol was concluded between ANAF and the Public Ministry in 2013, which is still in force. It provides for mutual support regarding the relevant information and data resulting in relation to the possible perpetration of criminal provisions that constitute customs offenses. The protocol also created the framework for setting up of joint teams under the supervision of a prosecutor.

At the same time, the protocol stipulates that anti-fraud inspectors will carry out their activity within the prosecutor's offices, on positions of economic-financial specialists.

Nonetheless, ANAF has the legal obligation to notify the criminal prosecution bodies in case it finds out of a deed that could constitute an offense. 
Concerning the effectiveness of cooperation, as can be seen from the mentioned criminological data, it is difficult to assess the magnitude of the phenomenon in Romania. As a consequence, the efficiency of the authorities in combating illicit trade of tobacco products cannot be determined, since the collection of these data has not been systematically and annually carried out by the authorities.

The main problem for the authorities is to determine the chain travelled by tobacco products from the introduction into the country to the final consumer, so that all the persons involved in the illicit trade of tobacco can be held accountable. This is the hard task because such products go through different intermediaries.

Moreover, the introduction of tobacco products is sometimes carried out by citizens of the neighbouring states. As such, the investigation becomes more difficult in the absence of effective cooperation with the neighbouring states.

At the same time, another problem encountered in combating illicit trafficking with tobacco is the lack of personnel and, correlatively, the increase in the volume of work/person related to the cases of illicit trafficking notified, which leads to a longer time to complete the investigations, and thus the effect the deterrent to punishment is diminished.

In view of the problems identified above, the increase of the number of civil servants, the increase of the funds allocated to fight illicit trade, as well as a better cooperation between Romania and the neighbouring states, from which the smuggling cigarettes are being imported into the country, would increase the efficiency of the authorities, consequently reducing the level of illicit trade in tobacco products.

\subsubsection{Procedural Rules}

The criminal prosecution bodies can proceed ex officio, or as a result of a notification from ANAF or any other person. In case of a notification from ANAF, the administrative procedures are suspended, in order to avoid infringing the ne bis in idem principle. The next phase is the investigation stage in rem, in which criminal investigation is carried out to establish the deed and the person who committed it. The next step is to begin the criminal investigation in personam, at which point an individual is officially notified that he is a suspect.

Investigations are still being carried out, and if the evidence shows a reasonable suspicion that an offense has been committed by that particular individual he will be indicted.

Thereafter, the indicted individual has the possibility to conclude a pleaagreement with the prosecutor. In the event that such an agreement is not conclude, the prosecutor will proceed to trial.

The prosecutor, the preliminary chamber judge or the court, can take different preventive measures in order to avoid the concealing, destroying or alienating goods that may be seized or which can serve to guarantee the execution of the fine or the legal expenses or to repair the damage caused by the offense in question (as set forth in article 249 and article 254 of the Criminal procedure code). 
The only authority that would have a special competence in prosecuting offenses related to illicit trafficking would be the Border Police. In OUG [Government Ordinance] no. 104/2001, it is stipulated under art. 21 letter u) that it is the Border Police that carries out the criminal investigation activities and, through the criminal investigation bodies of the judicial police within the Romanian Border Police, carries out investigations in connection with them, according to the law, but only in its area of competence.

The area of competence is the area of the national territory consisting of the border area, the surface and the buildings of the airports and ports located inside the country, opened for international traffic, as well as the contiguous area and the exclusive economic zone of Romania, where the Romanian Border Police performs its duties provided by law; as well as the entire territory of the national territory, only for fulfilling the tasks related to the prevention and combating of illegal migration.

There are no specific criminal intelligence activities undertaken by national authorities with regard to investigating illegal trade of tobacco. Even in the pre-trial phase the prosecution body can ask a judge to authorize a special surveillance method consisting in access to a computer system, intercepting communications, phone tapping etc.

Article 138 of the Criminal Code of Procedure provides for the following special surveillance or research methods: (a) intercepting communications or any kind of remote communication; (b) access to a computer system; (c) video, audio or video surveillance; (d) location or tracking by technical means; (e) obtaining data on a person's financial transactions; (f) detention, surrender or search of postal items; (g) use of undercover investigators and collaborators; (h) authorized participation in certain activities; (i) supervised delivery; (j) obtaining traffic and location data processed by providers of public electronic communications networks or providers of publicly available electronic communications services. All these can be used as special investigative techniques in order to obtain evidence in regard to illegal trade of tobacco.

\section{Criminological Data}

\subsection{Offenses}

In these annual activity reports no distinction is made between illicit trade of tobacco products and smuggling of other products (e.g. alcohol). Taken into consideration these general official data we cannot conclude in regard to the total number of cases of illicit trade of tobacco products per year (Tables 2 and 3).

Concerning the cases of illicit trade/smuggling of tobacco products following data is available (Tables 4 and 5).

It is worth mentioning that an indictment act may include more than one individual. 
Table 2 Criminological data in regard to the number of solved smuggling criminal cases

\begin{tabular}{l|l|l|l|l|l|l|l}
\hline Year & 2011 & 2012 & 2013 & 2014 & 2015 & 2016 & 2017 \\
\hline $\begin{array}{l}\text { Number of solved criminal cases } \\
\text { regarding smuggling offenses }\end{array}$ & 1657 & 1766 & 1774 & 1908 & $\begin{array}{l}\text { No avail- } \\
\text { able data }\end{array}$ & $\begin{array}{l}\text { No avail- } \\
\text { able data }\end{array}$ & 2472 \\
\hline
\end{tabular}

Source: Annual activity reports of the Prosecutor's Office attached to the High Court of Cassation and Justice (Available at http://www.mpublic.ro/ro/content/raport-de-activitate. These annual activity reports are available starting with 2011)

Table 3 Criminological data in regard to the number of pending smuggling criminal cases

\begin{tabular}{l|l|l|l|l|l|l|l|l}
\hline Year & 2010 & 2011 & 2012 & 2013 & 2014 & 2015 & 2016 & 2017 \\
\hline $\begin{array}{l}\text { Number of pending criminal cases } \\
\text { (old cases and new cases) }\end{array}$ & 1052 & 695 & 435 & 463 & 563 & 788 & 588 & 667 \\
\hline
\end{tabular}

Source: Annual activity reports of the Directorate for Investigating Organized Crime and Terrorism-DIICOT

Also, it must be emphasised that DIICOT investigates offenses regarding illicit trade/smuggling of tobacco products only if they were committed by an organized criminal group (art. 367 of the Criminal Code). According to the 2017 and 2018 annual activity reports of the DIICOT, investigations regarding organized criminal groups who commit crimes related to illicit trade/smuggling of goods represent $3 \%$ in 2017 and $2 \%$ in 2018 of the total number of investigations conducted by them.

In regard to the estimated financial impact of illicit trade, in particular smuggling, of tobacco products the data is presented in Table 6.

There is no conclusive data available on conviction for illicit trade/smuggling of tobacco products. The only data available is relating to the number of people incarcerated, who were convicted for criminal offenses stipulated in the Romanian Customs Code, but this data in not conclusive because a person might be convicted for illicit trade/smuggling of tobacco and not be serving the sentence in prison, as it was suspended.

Taken into consideration the available data from the annual activity reports of the Directorate for Investigating Organized Crime and Terrorism [DIICOT] we can conclude that customs offenses (provided in Law no. 86/2006) are most often committed in concurrence with the organized criminal group offense (article 367 of the Criminal Code).

The only data available in this regard is relating to the number of people incarcerated, who were convicted for criminal offenses stipulated in the Romanian Customs Code (Law no. 86/2006). There is no data available for any suspended prison sentences or any other penalties or measures applied in regard to perpetrators (Table 7).

There is no available data on the subject of convictions of legal entities.

Also, there is no available data on characteristics of perpetrators of illicit trade of tobacco products. 


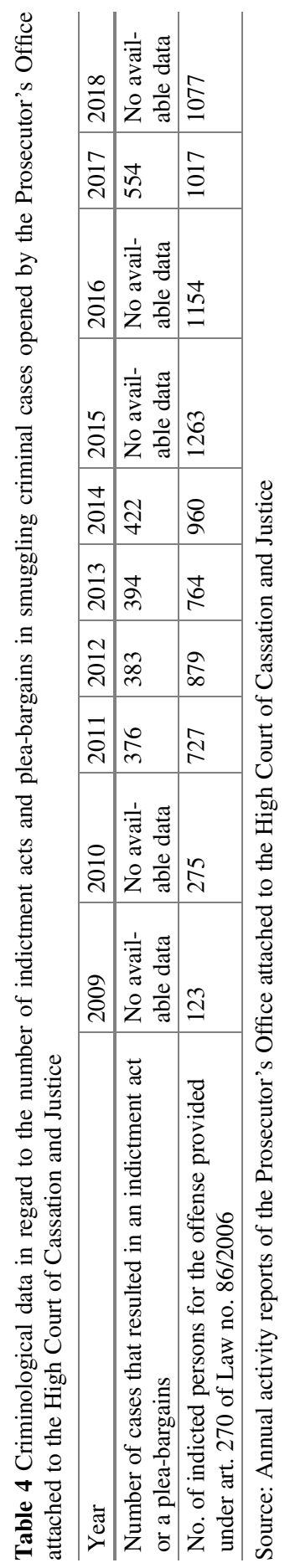


Table 5 Criminological data in regard to the number of indictment acts and plea-bargains in smuggling criminal cases opened by the Directorate for Investigating Organized Crime and Terrorism - DIICOT

\begin{tabular}{l|c|c|c|c|c|c|c|c|c}
\hline Year & 2010 & 2011 & 2012 & 2013 & 2014 & 2015 & 2016 & 2017 & 2018 \\
\hline $\begin{array}{l}\text { Number of cases that } \\
\text { resulted in an indictment } \\
\text { act or a plea-bargains }\end{array}$ & 63 & 42 & 25 & 15 & 24 & 40 & 17 & 25 & 27 \\
\hline $\begin{array}{l}\text { Number of indicted } \\
\text { persons }\end{array}$ & 190 & 223 & 277 & 149 & 162 & 330 & 212 & 237 & 193 \\
\hline
\end{tabular}

Source: Annual activity reports of the Directorate for Investigating Organized Crime and Terrorism-DIICOT

\subsection{Financial Impact of Illicit Trade}

In the Reports of the Prosecutor's Office attached to the High Court of Cassation and Justice, the damage caused by offenses prosecuted in 2014 was estimated at 51.904.671 lei (cc. 11.7 million euros) and 56.329 euros. The damage caused by offenses prosecuted in 2013 was estimated at 8.000.073 lei (cc. 1.8 million euros), to which is added about 135 million euros.

There is no available data concerning asset recovery related to illicit trade of tobacco products. In the Reports of the Prosecutor's Office attached to the High Court of Cassation and Justice the following data is available:

- in 2017, goods amounting to 58.739.248 lei (cc. 12,9 million euros) were seized and preventive measures were instituted in regard to goods worth 5.000.000 euros;

- in 2014, preventive measures were instituted in regard to goods worth 11.788 .763 lei (cc. 2.6 million euros).

In regard to 2015-2016, there is no specific data, and for 2011-2013, the numbers are not broken down for each offense (they also include money laundering, tax evasion etc.).

The annual performance reports of the National Agency for Fiscal Administration [ANAF] specify the following:

- in 2018 were seized 45.3 million pcs. of cigarettes and $609.7 \mathrm{~kg}$ of tobacco.

- in 2017 were seized 61.8 million pcs. of cigarettes and $7056.58 \mathrm{~kg}$ of tobacco.

- in 2015 were seized $69,531,890$ pcs. of cigarettes and 2.53 tons of bulk tobacco.

- in 2014 were seized 62,604,599 pcs. of cigarettes and 10.9 tons of bulk tobacco. 
Table 6 Criminological data in regard to smuggling volume quota

\begin{tabular}{|c|c|}
\hline Month/Year & Volume quota/smuggling \\
\hline August 2008 & 15.8 \\
\hline November 2008 & 19.6 \\
\hline February 2009 & 18.2 \\
\hline April 2009 & 22.2 \\
\hline July 2009 & 20.1 \\
\hline January 2010 & 36.2 \\
\hline March 2010 & 33.9 \\
\hline May 2010 & 26.8 \\
\hline July 2010 & 21.3 \\
\hline September 2010 & 24.4 \\
\hline November 2010 & 22.8 \\
\hline January 2011 & 22.5 \\
\hline March 2011 & 14.7 \\
\hline May 2011 & 11.8 \\
\hline July 2011 & 15.7 \\
\hline September 2011 & 11.8 \\
\hline November 2011 & 15 \\
\hline January 2012 & 13 \\
\hline March 2012 & 13.4 \\
\hline May 2012 & 13.3 \\
\hline July 2012 & 12.9 \\
\hline September 2012 & 14.2 \\
\hline January 2013 & 15.4 \\
\hline March 2013 & 13.1 \\
\hline May 2013 & 12.6 \\
\hline July 2013 & 11.8 \\
\hline September 2013 & 15 \\
\hline November 2013 & 14.1 \\
\hline January 2014 & 15.7 \\
\hline March 2014 & 15.8 \\
\hline May 2014 & 16.1 \\
\hline July 2014 & 17 \\
\hline September 2014 & 15.4 \\
\hline November 2014 & 15.4 \\
\hline January 2014 & 19.2 \\
\hline March 2015 & 15.2 \\
\hline May 2015 & 14.1 \\
\hline July 2015 & 15.3 \\
\hline September 2015 & 14.8 \\
\hline November 2015 & 17.5 \\
\hline January 2016 & 17.8 \\
\hline March 2016 & 14.6 \\
\hline May 2016 & 16.9 \\
\hline
\end{tabular}

Source: Novel Research (Available on https://www. novelresearch.ro/comertul_ilicit/) 


\section{Exemplary Case of Illicit Trade}

A relevant decision is from the Cluj Court of Appeal. ${ }^{22}$ The case is exemplary because it illustrates the route of cigarettes from the introduction into the country to the final consumer. Thus, a number of 15 individuals were sent to court and convicted for committing the smuggling offenses [art. 270 para. (1) and (3) with the application of art. 274 of Law 86/2006]. From the total of 15 accused individuals, 7 of them were also accused for being part of an organized criminal group (article 367 of the Criminal Code).

The criminal activity of the defendants is presented in 3 different stages. At Stage 1 , an introduction of tobacco products into the country takes place. The first category of defendants is represented by those involved with the introduction of the cigarettes into the country. Thus, the leader of the criminal group was a citizen from a locality near the border (A), a Ukrainian-speaking person, who was traveling to Ukraine and buying cigarettes from Ukrainian citizens. The cigarettes were actually carried across the border by Ukrainian citizens, the defendant along with another person (B), also accused and convicted, ensuring only the safeguard of the route that the Ukrainian citizens were to follow. Cigarettes were transported to B's home. From B's house, part of the cigarettes was subsequently moved to A's house, each of them having to deal with their subsequent distribution. In principle, cigarettes were sold in larger quantities to people who in turn resold them. However, they also sold cigarettes in smaller quantities to final consumers, specifically to people living in the same city as them.

Stage 2 refers to the sale of tobacco products to the first buyers. The second category of defendants is represented by the first buyers of cigarettes, who took them from the defendants $\mathrm{A}$ and $\mathrm{B}$, and then wholesale them at a higher price to different other people. In this activity were involved people who only deal with the transport of cigarettes from one location to another, persons also accused and convicted.

Stage 3 consists in the sale of tobacco to the final consumers. The third category of defendants is represented by those who bought the cigarettes from the defendants of the second category, and then they marketed them to the final consumers. These people either traded cigarettes in markets or traded them through the grocery stores they owned.

\section{Methods and Other Phenomenological Details Related to Illicit Trade of Tobacco Products}

On the website of the Romanian Border Police ${ }^{23}$ there is a brief presentation regarding methods of smuggling and the relation to the organised crime.

\footnotetext{
${ }^{22}$ See Cluj Court of Appeal, criminal section, decision no. 122/2016. www.rolii.ro/hotarari/ 589b6e14e490095c2f001557. Last accessed 21 April 2020.

${ }^{23}$ See Romanian Border Police website. www.politiadefrontiera.ro. Last accessed 20 April 2020.
} 
Table 7 Criminological data in regard to the number of incarcerated individuals

\begin{tabular}{l|l|l|l|l}
\hline Month/Year & $\begin{array}{l}\text { December } \\
2016\end{array}$ & $\begin{array}{l}\text { March } \\
2017\end{array}$ & $\begin{array}{l}\text { December } \\
2018\end{array}$ & $\begin{array}{l}\text { November } \\
2019\end{array}$ \\
\hline $\begin{array}{l}\text { Number of individuals incarcerated for crimes } \\
\text { stipulated in the Romanian Customs Code }\end{array}$ & 286 & 299 & 258 & 273 \\
\hline
\end{tabular}

Routes used for smuggling are identifies as follows. At the northern border (Maramureș, Suceava, Satu Mare counties), cigarettes of Ukrainian origin are prevalent, smugglers being organized into real criminal groups, with segments abroad, at the border and inside the country. They are trying to pass the packages of cigarettes over the "green" border, especially at night. At the eastern border (Galați, Vaslui, Iași, Botoșani counties), cigarettes of origin from the Republic of Moldova are predominant (lower quality cigarettes-Plai, Doina, Plugarul, MT), their introduction into the country being made through border points, either in large quantities, in specially arranged means of transport, or in small quantities individuals. In the south-western counties of the country (Caraş-Severin, Mehedinți, Timiş), generally, medium and superior quality cigarettes, purchased from duty-free shops and transported across the border, in small quantities by individuals.

In addition, the following methods used for smuggling are identified by the Romanian Border Police. The first one is called "cap" method. It consists in concealing cigarette packages among other categories of goods, legally transited through the border crossing points. Second one is "proofing" of cars with cigarettes, consisting of hiding the packages in their various component parts (tires, side rails, doors, etc.) or the use of double walls. Perpetrators also use concealment of cigarettes in clothing or glued on the body, in other food packaging or in doublebottomed bags. The "cable" method is used in the area of the river border; it involves the passage of cigarette bottoms on a cable fixed on the two banks of the watercourse. In addition, the perpetrators transit the mountainous border area with horse drawn trailers, taking advantage of the difficult accessible mountainous terrain, which makes it difficult for authorities to check the routes. They also use flight devices-moto-hang gliders, or gliders or drone, which are modified for transport of cigarettes across the border.

\section{Preventive Measures}

The aspects regulated by the Convention and even by the Protocol of 2012 are transposed by Law no. 201/2016 and by Law no. 47/2004. The track \& tracing system is in conformity with the protocol and has entered into force as of October 31, 2019. Advertising for tobacco products is prohibited, as stipulated in the Convention, being allowed only in publications exclusively intended for professionals in the trade of tobacco products and in publications that have not been 
published or printed in Romania or in a Member State of the Union. They are neither European nor intended mainly for the Romanian or the Community market.

The appearance of cigarette packages is regulated in detail, being mandatory to present the warning messages on them (e.g.: smoking kills, etc.), and from this perspective the Romanian legislation being in accordance with the Convention.

The efficiency of the measures is relevant, first of all, from the fact that the appearance of the cigarette package (the fiscal stamp, the language in which the warning messages are played, etc.) can raise the consumer's suspicions about its origin, which would - in theory - discourage him from purchasing such a product. Since there is no retail market, illicit tobacco traffic would be significantly reduced.

But the problem is that although these preventive measures are effective in terms of determining the origin of the cigarettes, they do not discourage people interested in purchasing smuggled products, as they are aware of their source. The main reason they want to buy them is the reduced cost.

In regard to the track and tracing system, being recently implemented ( 2 months ago), we cannot assess its effectiveness.

The main way to prevent illicit trade of tobacco products is to carry out customs controls, as well as to protect the borders in order to prevent the introduction of products through places other than those established for customs control.

At the same time, the national institutions started a series of national campaigns to fight smuggling and illicit trade, through which citizens were informed about the legal consequences of the purchase/sale of smuggled products, but also about the negative impact on the national economy.

\section{Cooperation}

In the field of prevention, the relevant national institutions would be the National Agency for Fiscal Administration [ANAF] and Border Police.

As far as ANAF is concerned, the regional customs offices and the customs offices as subordinate units thereof, referred to as customs authorities, are established. The main task of the customs authorities is to carry out customs control of goods imported or removed from the country. Customs control shall be carried out at customs offices and customs posts by the customs authority, under the direction and control of the regional customs directorates and the National Agency for Fiscal Administration.

ANAF has the competence to establish the customs debt as well as to find contraventions and apply the sanctions in question.

According to OUG [Government Emergency Ordinance] no. 104/2001, the Border Police is a part of the Ministry of Administration and Interior and is the specialized institution of the state exercising its powers regarding the supervision and control of the state border crossing, the prevention and combating of illegal migration and the specific facts of cross-border crime committed to the area of competence, respecting the legal regime of the state border, passports and aliens, 
ensuring the interests of the Romanian state, the contiguous area and the exclusive economic zone, and public peace in the area of competence, under the law.

Between ANAF and the Public Ministry a cooperation Protocol was signed in 2013, which is still in force. It provides for mutual support in relation to relevant information and data on possible deeds which could constitute customs offenses and the establishment of joint teams to act on the basis of action plans under the direction and the coordination of prosecutors.

At the same time, the protocol provides that anti-fraud inspectors will carry out their activity in the prosecutor's offices, as economic and financial specialists.

The ANAF also has the obligation to notify the criminal investigating authorities when it finds that they committed a crime that could constitute an offense.

Concerning the Border Police, the OUG [Government Emergency Ordinance] no. 104/2001 states that annual cooperation protocols can be concluded between the authorities of the local public administration and the territorial units of the border police in order to prevent and combat antisocial deeds. The Border Police General Inspectorate cooperates with central public administration authorities, judicial bodies, other central bodies and institutions of the state, as well as representatives of civil society. On a territorial level, the structures subordinated to the Border Police General Inspectorate cooperate with the local public administration authorities, the judicial bodies, the other state bodies and institutions, the decentralized ministries, as well as representatives of the civil society. Border Police General Inspectorate collects, stores, processes, exploits and exchanges data and information, under the conditions established by the law for the Romanian Police, in order to exercise its legal attributions, with the interested public authorities, on a protocol basis.

The cooperation between the Romanian Border Police and the other structures of the Ministry of Administration and Interior for securing the state border and combating cross-border crime is carried out on the basis of the order of the Minister of Interior.

Concerning ANAF, the Tax Procedure Code provides in article 71 that based on international conventions, tax authorities must cooperate with similar tax authorities in other states. But in the absence of a convention, the tax authorities may grant or may require the collaboration of another tax authority in another State on the basis of reciprocity. ANAF, as an authorized representative of the Ministry of Public Finance or, as the case may be, of the Minister of Public Finance, is the competent authority in Romania to exchange information for fiscal purposes with the states with which Romania has committed itself by a legal instrument international law, other than the Member States of the European Union, for the information provided by those legal instruments of international law.

Concerning the Border Police, the OUG [Government Emergency Ordinance] no. 104/2001 states that the Border Police has the task of concluding treaties, through the General Inspectorate of Border Police, and international cooperation documents with similar authorities from other states in the specific fields of activity, in compliance with the relevant national legislation and relevant international law. Also, the Border Police organizes and carries out cooperation, in the specific fields of 
activity, with similar bodies of neighbouring states, other states or communities of states, according to bi- or multilateral agreements to which Romania is a party;

Concerning the cooperation with EU Member State institutions, the Customs Code only stipulates that the National Agency for Fiscal Administration is designated as the competent authority to apply to Romania at the date of accession to the European Union the provisions of the Convention on the Use of Information Technology by Customs and the Convention on Mutual Assistance and Cooperation between customs administrations.

Furthermore, Border Police cooperates with the Frontex Agency for securing the external borders of the European Union. In this respect, in OUG [Government Emergency Ordinance] no. 104/2001 it is specified that the Romanian Border Police cooperates with the other structures of the Ministry of Administration and Interior and with other institutions in the system of defence, public order and national security in order to ensure the logistic resources and personnel for the participation to joint operations/activities organized by the Frontex Agency (European Institution) to secure the external borders of the European Union, as required by the mission (see article $25^{1}$ ).

\section{General Issues}

A first factor contributing to the illicit trafficking of cigarettes in Romania is the low income, the gross minimum wage being about 300 euros/month, while the incomes from the illicit trafficking of cigarettes are much higher, which corroborated with the lack of jobs in rural areas and especially those close to the borders determine the increase in the level of illicit traffic.

At the same time, in Romania the consumption of tobacco among the population over the age of 15 is 28\% (According to Eurobarometer 2017, made by the European Commission and published on the occasion of the World Day without Tobacco), which, again, corroborated with the low incomes, determines people to buy cigarettes from smuggling, because of their lower price.

Concerning the general political and institutional factors which may contribute to the illicit trade of tobacco products in Romania, lack of funds and staff, as well as high corruption both in neighbouring countries and in Romania should be pointed out.

There are some geographical circumstances, which must additionally be mentioned. The first factor contributing to the illicit trafficking of cigarettes in Romania is its geographical positioning, with Romania having longer borders with the states that are not members of the European Union, namely Ukraine, Moldova, Serbia. A second factor is the opening to the Black Sea, through the port of Constanța which is also used to illegally import cigarettes into the country.

The available statistical data indicates that most cigarettes were seized in the South-east area (Constanța port), and North-east and North-west (border with Ukraine and Moldova) as well as in the West zone (border with Serbia). 


\section{Conclusions}

The Romanian legal framework for illicit tobacco trade/smuggling is a complex one. There are a variety of offenses and a problematic partial overlap with the administrative liability. The fact that in some situations the same deed can raise a criminal or an administrative liability puts into question the lack of legal certainty.

Sergiu Bogdan Ph.D., is Professor at the Babeș-Bolyai University, he teaches the following courses: Criminal Law - Special Part, Business Criminal Law and Criminology; he is also doctoral supervisor in the field of criminal law. He wrote numerous scientific papers in the field of criminal law. Prof. Bogdan is also the founder and leading partner lawyer at "Sergiu Bogdan \& Associates" law firm, specialised in criminal law. He is a member of European Criminal Policy Initiative (www. crimpol.eu) and co-author of the Manifesto on European Criminal Policy (first published in ZIS 2009, pp. 697-747, updated in EuCLR 2011, pp. 86-103), the Manifesto on European Criminal Procedure Law (first published in ZIS 2013, pp. 412-446) and the Harmonisation of Criminal Sanctions in the European Union (Herausgegeben von Prof. Dr. Helmut Satzger, Nomos Publishing, 2020).

Open Access This chapter is licensed under the terms of the Creative Commons Attribution 4.0 International License (http://creativecommons.org/licenses/by/4.0/), which permits use, sharing, adaptation, distribution and reproduction in any medium or format, as long as you give appropriate credit to the original author(s) and the source, provide a link to the Creative Commons licence and indicate if changes were made.

The images or other third party material in this chapter are included in the chapter's Creative Commons licence, unless indicated otherwise in a credit line to the material. If material is not included in the chapter's Creative Commons licence and your intended use is not permitted by statutory regulation or exceeds the permitted use, you will need to obtain permission directly from the copyright holder. 